\title{
Staging Penance: Scenes of Sacramental Confession in Early Modern Spanish Drama
}

\author{
Hilaire Kallendorf
}

\begin{abstract}
Scholars now recognize that the language of casuistry pervades early modern Spanish school dramas, comedias and autos sacramentales, due to the Jesuit education received by a majority of Renaissance Spain's renowned playwrights. A closer scrutiny of a corpus of 8 oo digitalized plays from this period - supplemented by plays held in manuscript at Madrid's Royal Academy of History - reveals an even closer connection between the ritual act of the Catholic Church's sacrament of confession and the early modern Spanish stage.
\end{abstract}

\section{Keywords}

Penance - confession - casuistry - Jesuits - school dramas - comedias - autos sacramentales - ritual - sacrament

Sacramental confession in the comedias, autos sacramentales and Jesuit school dramas appears in everything from short off-the-cuff references to extended scenes to even play titles and main themes. This is the case not only in early modern Spanish drama but also on the stage in early modern England:

The traditional [penitential] rite appeared with noticeable regularity in almost every dramatic genre, ranging from early modern history plays (Peele's Edward I and Shakespeare's Henry VIII) to comedies and tragedies set in Catholic countries (Measure for Measure, Romeo and Juliet, Much Ado About Nothing, and Ford's 'Tis a Pity She's a Whore) to anti-Catholic polemical dramas (Bale's King Johan, Marlowe's Jew of Malta, Webster's The Duchess of Malfi, and Middleton's A Game at Chess). Either in terms of England's religious past or contemporary examples on the Continent, the connection between ritual confession and Roman Catholicism 
constitutes the common theme in the majority of early modern dramatic representations of the rite.

STEGNER 107

I was perhaps the first to point out that "vernacular Jesuit dramas form a lynchpin of the case for finding a new basis of an alternative poetics for the comedia in the techniques of casuistry" (Kallendorf 2007: 12). In recent years, however, increasingly scholars are beginning to trace the relationships among these three kinds of theatrical production (i.e. 'secular' comedias, Jesuit school dramas, and the more liturgical autos sacramentales) and to recognize that they are not so easily disentangled from one another as previous generations of researchers might have thought. ${ }^{1}$ More and more often now, one finds declarations of mutual influence and synergy such as "podemos inferir la influencia del teatro comercial en el de colegio a través de los profesores y estudiantes en su papel de espectadores" (Montiel Contreras 67).

It has by now been established that casuistry, or case morality, forms the basis for a poetics of early modern Spanish theatrical production. ${ }^{2}$ But up until this point the study of casuistry in the drama has focused on topics such as the recurring question "¿Qué he de hacer?" along with descriptions of a clean or guilty conscience; the appearance of trademark phraseology from the casuists' linguistic register such as casos, indicios, circunstancias, motivos, laberintos (Kallendorf 2019); and the negotiation of particularly thorny ethical dilemmas such as the classic double bind (Kallendorf 2007). What has been lacking is the scrutiny of scenes where the actual sacrament (or its equivalent) appears, given that casuistry as a discourse finds a point of origin inside the confessional box. Montiel Contreras highlights the importance of confession scenes for Jesuit drama specifically:

Los jesuitas recorrían el escalafón social por medio de la confesión, ya que el sacramento era clave y expresión de la fe o de la conversión del creyente y marcaba su inicio hacia el camino de la salvación [...] Si el hombre gozaba de albedrío para evitar el pecado y superar la tentación, se debía a la guía de conciencia y a la confesión suministradas por la

1 For further instances of cross-fertilization among early modern Spain's various dramatic traditions, see González Gutiérrez 1991 and González Gutiérrez 1997.

2 As Antonio Sánchez Jiménez asserts of my Conscience on Stage, "Este trabajo fue pionero en el campo y se revela una obra de consulta tan obligada como útil” (Sánchez Jiménez 577). 
Compañía, que intentó por todos los medios - y el teatral fue uno de los predilectos - reducir esa posibilidad física y moral de que los devotos erraran sus pasos.

MONTIEL CONTRERAS 60

This chapter will analyze six representative plays by four playwrights, from a variety of genres, to determine what we can learn about early modern casuistry in its explicitly sacramental form through its portrayal on the stage.

As I noted in Conscience on Stage: The Comedia as Casuistry in Early Modern Spain: "the school dramas are rife with references to sacramental confession" (Kallendorf 2007: 28). However, I only devoted a single page of that book to describing some of these references. One occurs in Francisco Ximénez's Diálogo hecho en Sevilla when the character Dolus declares: "Confieso las cuaresmas/ como los buenos cristianos" (Ximénez, vv. 2208-2209, 1: 380). Another is in Juan Bonifacio's Triumphus Circuncisionis when Circuncisio asserts, "Pareçe me amí que era neçessario aun maestro guardar grauedad paternal, dando buenos consejos alos disçipulos haziendolos confessar amenudo" (Bonifacio, Triumphus Circuncisionis: 31v).

I did not in that book discuss scenes of sacramental confession per se in the autos sacramentales or 'secular' comedias. In the category of off-the-cuff or humorous remarks about the sacrament of penance in these other kinds of plays, we might include the following humorous dialogue between Rodulfo and Carloto in Lope de Vega's El Marqués de Mantua (1596): ${ }^{3}$

$\begin{array}{ll}\text { Carloto: } & \begin{array}{l}\text { Que al Rey es mucha justicia } \\ \text { darle aquello que codicia. }\end{array} \\ \text { Rodulfo: } & \begin{array}{l}\text { Cuando codicia lo injusto, } \\ \text { no es justicia hacerlo justo, } \\ \text { sino pecado y malicia. }\end{array} \\ \text { Carloto: } & \text { ¿Pecado? } \\ \text { Rodulfo: } & \text { Pecado digo. }\end{array}$

3 This is the date of a manuscript of the play held in the Colección Gálvez (Antonucci 2005: 64, n. 17), so named for the copyist Ignacio Gálvez (Pedraza Jiménez 2007b: 17). As Felipe Pedraza points out, this date places the work near the end of the first phase of Lope's career, with its composition occurring shortly before the closing of theaters 1597 due to Catalina de Saboya's death: "El marqués de Mantua de Lope de Vega, se acabó de redactar, según el manuscrito Gálvez, el 10 de enero de 1596, es decir, hacia el final de la primera etapa de la dilatada trayectoria del dramaturgo, poco antes de la suspensión de las representaciones en 1597, a raíz de la muerte de Catalina de Saboya" (Pedraza Jiménez 2007: 129). 


\section{Carloto: ¡Qué teólogo revuelvo! ¿Confiésome yo contigo? \\ Rodulfo: $\quad$ Pues por eso no te absuelvo. LOPE DE VEGA, acto 1, Vv. 196-204, 36-37}

Luisa Rosselló Castillo sums up the picture presented in this scene: "A través de Carloto, se escenifica lo que ocurre cuando un príncipe es incapaz de domeñar sus pasiones y de controlar sus impulsos" (166). The text's modern editor, Felipe Pedraza, adds the following gloss to this passage: "Las ideas políticas aquí desarrolladas vienen a coincidir con las que hacia 159 o consignaba Juan de Mariana en De rege et regis institutione, en especial en el cap. V del libro I" (Lope de Vega, 36 n189-210). He also notes that Mariana's book was burned publicly in Paris after the assassination of Henri IV (Pedraza Jiménez 2007b: 28). Rosselló Castillo even demonstrates that Lope de Vega knew the Jesuit priest Juan de Mariana personally and wrote him two letters in 1620, in one of which he specifically requests that Mariana send him two texts on the topic of "la razón con que se pueda gobernar un señor en sus estados, así personalmente como con sus súbditos y vasallos, y en la administración de su justicia y segura conciencia tratar las jurisdiciones eclesiásticas y seglares y acudir a toda obligación cristianamente" (Lope de Vega, Epistolario 280, quoted in Rosselló Castillo 150).

Here we find a seemingly humorous exchange with serious undertones about a prince wanting what he should not have - in this case, his cousin's wife - and pushing past the limits of royal authority. ${ }^{4}$ The object of Carloto's desire is the Muslim princess Sevilla, recently wedded to Baldovinos. Carloto - still a prince,

4 Pérez García confirms that this passage of Lope's play contains "la reflexión sobre los límites del poder de un rey y el conflicto entre los derechos de sus súbditos y la voluntad y el deseo de su señor [...] El problema que se desarrolla en la obra no es cuestionar la autoridad real sino discutir los derechos y limitaciones de poder de un rey injusto [...] El problema se presenta cuando se confunden las leyes con el poder arbitrario, con la tiranía" (Pérez García 2001, 191, 195). Rosselló Castillo sees this play of Lope's as part of a more general pattern or subgenre of works in which the playwright meditates on the nature of monarchy: "el interés de estas [...] ]obras radica en el hecho de que Lope juegue a mostrarnos a un joven representante de la monarquía que no se ajusta a un modelo ideal, que no se comporta tal y como se esperaría de él [...] Es la actuación de estos [...] herederos a la corona la que se convierte en el desencadenante del conflicto dramático y provoca situaciones controvertidas o espinosas que permiten a Lope plantear sus dudas y reflexiones sobre lo que implica ser rey y sobre qué se debe hacer cuando un representante de la monarquía no obra como le corresponde. Son obras que resultan sugestivas, de igual modo que lo son otras comedias en las que es el mismo rey quien sucumbe a una pasión amorosa no correspondida, o bien, no conveniente" (Rosselló Castillo 149). 
not yet a king - is the son of Charlemagne; he uses his rights as heir to the kingdom to justify indulging his adulterous desires: "Carloto se recuerda a sí mismo su condición real para justificar así, primero, sus adúlteras intenciones con Sevilla, y después el premeditado asesinato de su marido Valdovinos" (Espín Templado 169). Espín Templado describes the mental contortions Carloto goes through in an attempt to justify his actions:

El móvil del asesinato es, pues, la pasión, pero el pretexto que sirve a Carloto para acallar su conciencia, será su sangre regia, esto es, el ser príncipe heredero; este poder real es lo que le confiere, según sus falaces razonamientos y los de su mal consejero Galalón, el derecho de hacer su voluntad, basándose en una errónea concepción del poder de la monarquía. (168)

This scholar also notes the malign influence of Carloto's counselor Galalón in persuading him to embark upon an immoral course of action: "Galalón intenta persuadir a Carloto de los derechos ilimitados que le confiere su sangre real, convenciéndolo además de que si en algo se extralimita, el Rey le perdonará por ser su padre" (Espín Templado 170). Pérez García notes that Galalón has a personal motive of revenge for leading Carloto astray: "La presencia de Galalón en la traición tiene su importancia ya que es él quien ha sugerido a Carloto la muerte de Valdovinos y quien se venga personalmente de una afrenta anterior" (Pérez García 194). This personal affront was a slap to the face Galalón had received from one of Baldovinos's relatives. Pérez García also insists that Carloto knows what he is doing is wrong and never fully manages to convince himself that his actions are justifiable:

En efecto, Carloto sabe desde el principio que su acción es injusta y pide perdón a Dios. Pero en lugar de quitar de sí la tentación, primero intenta forzar la voluntad de Sevilla. Pero como sabe que el matrimonio está por encima, como sacramento, de su autoridad, opta por eliminar el obstáculo que impide su satisfacción personal eliminando a Valdovinos.

PÉREZ GARCÍA 196

Intriguingly, Pedraza Jiménez sees a possible parallel between Carlomagno and his son Carloto in the play and the Spanish King Felipe II and his son Carlos in real life:

Esto se escribe en las postrimerías del reinado de Felipe II. Los contemporáneos pudieron ver en el Carlomagno dramático una contrafigura del rey prudente. No hay que olvidar que en la realidad histórica un heredero de la corona española había muerto confinado en el castillo de Arévalo. 
Don Carlos, el primogénito de Felipe II, falleció el 24 de julio de 1568. No parece haber duda sobre los trastornos sicofísicos del príncipe, pero también es cierto que en su insania fantaseó con huir a los Países Bajos, probablemente con la intención quimérica de hacerse fuerte junto a los descontentos con la política de su padre [...] Carlomagno en el drama, Felipe II en la historia próxima someten a su primogénito a la ley general y no toleran sediciones en su apoyo.

PEDRAZA JIMÉNEZ 145-46

As we can see clearly from this scene's gravely serious political import, in reality it ends up not sounding funny at all. But most of the scenes which center around the sacrament of penance (or reconciliation, as it is now officially called by the Catholic Church) were never in fact meant to be funny, instead elaborating on the dire need for this religious ritual, whether it ends up being possible for the characters to consummate it or not. For example, in the same play by Lope de Vega the dying Baldovinos - who has been murdered by order of Carloto during a hunting trip in an effort to steal his bride, Sevilla - implores his servant Marcelo to go find him a priest to hear his last confession and administer extreme unction:

\begin{tabular}{|c|c|}
\hline $\begin{array}{l}\text { Baldovinos: } \\
\text { Marcelo: }\end{array}$ & $\begin{array}{l}\text { Llámame un confesor. } \\
\text { ¿Estás herido } \\
\text { de muerte? }\end{array}$ \\
\hline Baldovinos: & Luego un confesor me llama. \\
\hline Marcelo: & ¡O Carloto crüel! \\
\hline Baldovinos: & ¿Aún no eres ido? \\
\hline & Quien ama el cuerpo, el alma aquí desama. \\
\hline Marcelo: & $\begin{array}{l}\text { Voy en mi propio llanto convertido, } \\
\text { que el alma por los ojos se derrama. }\end{array}$ \\
\hline Baldovinos: & $\begin{array}{l}\text { ¡Triste de mí, que han muerto al señor mío! } \\
\text { ¡Jesús, nombre piadoso, en vos confío! }\end{array}$ \\
\hline & $\begin{array}{l}\text { Quiero sentarme aquí por animarme, } \\
\text { aunque desmaya la mortal flaqueza, } \\
\text { y al cielo, que me escucha, confesarme. }\end{array}$ \\
\hline
\end{tabular}

This scene starts to look for all the world like a do-it-yourself confession without the assistance of a priest. Ruiz del Vizo insists, however, that Catholic ritual is followed to the letter: "Baldovinos, antes de expirar, cumple con todos los preceptos de la religión católica, apostólica y romana, pide confesión, mira a la cruz, y tres veces en sus últimos momentos, pronuncia el nombre de Jesús" 
(62). Later in the play the servant Marcelo does manage to find a hermit (a Carthusian monk) to come to the aid of his master:

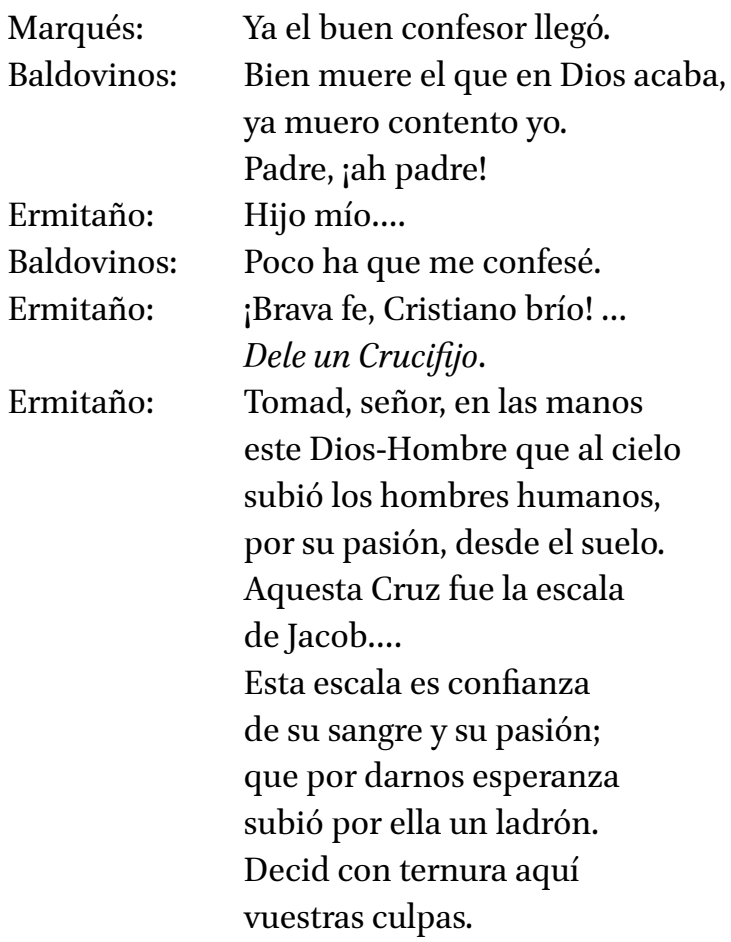

LOPE DE VEGA acto 2, vv. 1727-1749, 99-100

Chouza-Calo remarks concerning the extraordinary length of this scene, "Lope representa el momento en el que Valdovinos muere en brazos de su tío el Marqués de Mantua, pero lo hace escenificando una muerte agónica cargada de patetismo que se prolonga durante 386 versos [...] comparándola por momentos con la pasión de Cristo" (1). Ruiz del Vizo shares this heroic view of Baldovinos:

Baldovinos se presenta ante la vista de todos como cristiano perfecto. Atiende, en trance de muerte, a lo que un buen cristiano debe atender: a la salvación de su alma. Y atiende a ella antes que a la injusticia de su muerte. Su humildad llega al cenit. Un par, lejos de pedir justicia, como es de costumbre de acuerdo con las leyes de la nobleza y del feudalismo, sólo piensa en lograr la salvación en Dios [...] Es lo que puede llamarse una feliz muerte cristiana.

RUIZ DEL VIZO 52-53 
This longer confessional scenario sounds much less like a do-it-yourself version of the sacrament. But there is still no confessional box (first introduced by Carlo Borromeo after the Council of Trent), ${ }^{5}$ no how-to manual (confesionario or libro de confesores $),{ }^{6}$ no interrogation by the priest of the penitent regarding specific sins, and no formal absolution. The lack of absolution bears especially poignant resonances, as Paul Stegner explains for the early modern English context:

In the medieval administration of confession, penitents could ideally find inward assurance of the effectiveness of their spiritual performance of confession in its ritual form, especially through the priest's speaking of the rite of absolution and the laying on of hands.

STEGNER 112

So while he does in the end receive spiritual consolation from a priest, Baldovinos' confession happens without all the trappings of sacramental ceremony. Felipe Pedraza remarks upon the minimal role played by the Catholic Church in this play: "en el drama la iglesia no tiene más papel que el consuelo que presta 'un venerable cartujano' a Valdovinos en su agonía y a Carloto en el momento de subir al cadalso" (Pedraza Jiménez 2007:142).

In what is (in a sense) a similar example, albeit with opposite outcome, we turn from the open-air corrales of public theater in Spain to the Jesuit school dramas. With almost uncanny proto-Derridean logic, sometimes the sacrament of penance is most "present" on stage by virtue of its conspicuous absence. For instance, we might consider the case of a school drama by Juan Bonifacio. A Jesuit priest, professor and dramaturg, Bonifacio (1528-1606) was teacher to Saint John of the Cross (González Gutiérrez 1999: 3). He studied Latin and rhetoric at the University of Alcalá de Henares, but law at the University of Salamanca (Kallendorf 2012: 117). Juan Bonifacio's Tragedia Nabalis is a tragicomedy in five acts, composed ca. 156o-1575, and performed at a Jesuit college in Medina del Campo (González Gutiérrez 1999: 472, 488). In this play, Nabal's wife Abigail perceives that he is dying and urges him to confess his sins before it is too late:

5 "In Milan, the Archbishop Carlo Borromeo introduced (in 1565) a new wooden structure called a 'confessional' in which penitents could preserve their anonymity while confessing their sins" (Kamen 197).

6 The manuals of casuistry which proliferated so extensively during this time period have been studied by Elena del Río Parra. 
Abigail: Mirá, señor, que os morís y tenéis necesidad de descargar vuestra conciencia. Mirá que tenéis mucho de que dar cuenta. Proveéos dende ahora. Tened por gran misericordia de Dios este poquillo que os queda de vida. Momento es del cual depende una eternidad de siglos [...] Acordáos de aquella tía que tenéis pobre; mandadle alguna cosa, que es buena mujer. El pleito que trujistes con Alonso de los Hoyos fue injusto, y contra toda razón le hicistes gastar lo que no tenía. Hazedle alguna satisfacción ahora. ¿Qué os cuesta? ¿Habéislo de llevar con vos? Hazed cuenta que dais de lo ajeno. ¿Qué os cuesta? Sed liberal, siquiera en la muerte.

But Nabal persists without repenting:

Nabal: No acabará hogaño esta bachillera. Déjame, no sabes lo que dices. Yo he vivido muy limpiamente; no tengo de qué hacer escrúpulo. BONIFACIO 2001a, act 4, scene 2, 390-91

Nabal dies in his delusion. Montiel Contreras confirms, "La agonía de Nabal frente al público queda totalmente justificada no tanto por la ofensa ante David, sino por haber despreciado la ocasión para arrepentirse y examinar su conciencia frente a su esposa" (65). Similarly, in another play titled Actio Nepotiana by this same author, Juan Bonifacio, a female character named Sotela mourns for her unrepentant husband's spiritual death even more than for his physical one: “ $\mathrm{i}$ desastrada muerte sin confesión!" (Bonifacio, Actio quae inscribitur Nepotiana Gometius $5 \cdot 4,136 \mathrm{v}) .{ }^{7}$ Abigail goes on to marry none other than King David, which constitutes a considerable upgrade from her first husband, who was foolish and disagreeable. As the Biblical text explains, Nabal's name means "fool" (1 Samuel 25:25). In the Old Testament version Abigail says of her husband to King David: "Let not my lord the king, I pray, regard this naughty man Nabal: for according to his name, he is a fool, and folly is with him."

Still other works provide a contrast between failed and successful confessions within a single play through vignettes of different sinners and their repentance or lack thereof. As I put it in Conscience on Stage, invoking French philosopher Jacques Derrida, "There are also poignant scenes of confession and absolution in the school drama as well as Derridian lacunae where the absence of confession bespeaks its presence" (Kallendorf 2007: 28). A case in point is Juan Bonifacio's Triumphus Eucharistiae, an auto sacramental in five

7 My previous comment on this play still holds: "Here again we see a reference to sacramental confession and the painful consequences following its neglect" (Kallendorf 2007:32). 
acts, composed ca. 1567-1576, which was performed at the Jesuit Colegio de San Gil in Ávila (González Gutiérrez 1999: 472, 491) to celebrate the feast of Corpus Christi (Bernardo de Quirós Mateo 22, 231). Note the summary of the action read by Interpres at the start of the show:

Tratarse ha con el favor de Dios, en nuestra breve representación, un triunfo de la divina Eucaristía y Santíssimo Sacramento. Y porque los que bien comulgan reciben vida y, por el contrario, los que se llegan en pecado caen en muerte del alma, pareció ser traza conveniente introducir la Justicia divina, la cual ejecuta riguroso castigo en un pecador obstinado que no solamente vive mal, pero [i.e. sino] también persigue a los buenos y devotos. Después, la Caridad, reina y princesa de las virtudes, triunfará de cuatro hombres buenos y justos, en los cuales se cifran todos los estados y maneras de vivir que hay en la república cristiana, de suerte que al primero justiciarán los ministros de Dios, por indevoto y enemigo de los sacramentos y, finalmente, por malo y perverso; mas a los otros el amor divino los acariciará y sentará a la mesa y banquete celestial de la Hostia consagrada, porque [i.e. para que], emendados de sus faltas y descuidos comulgan con gran aprovechamiento suyo y buen ejemplo del prójimo.

BONIFACIO 20O1b: 610-11

Montiel Contreras explains the general function of the "Interpres" in the school dramas: "En esos prólogos un curioso personaje, el 'Intérprete', da aviso al público, siempre en lengua romance, de lo que pasará en cada uno de los actos" (63).

Eventually in Bonifacio's Triumphus Eucharistiae the allegorical figures of Justice and Charity come out onstage tied together with a knot, followed by a student actor who explains their appearance:

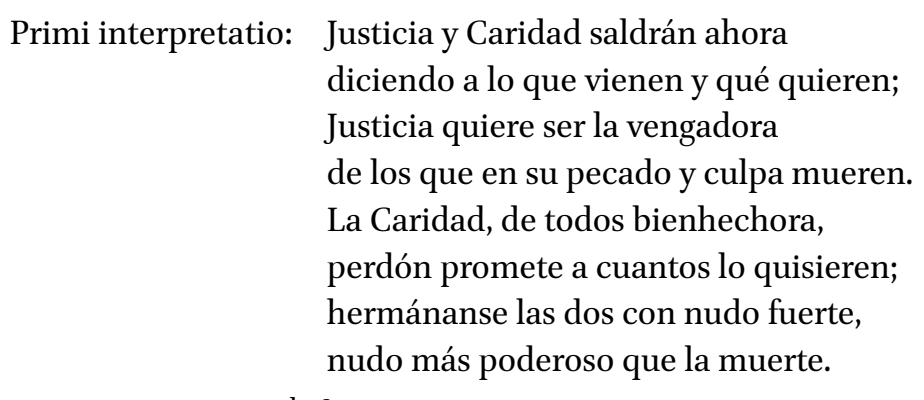

BONIFACIO 20O1b: 611

Justice appears on stage in an apotheosis as the goddess Astraea and urges the people to repent: 
Astraea: Yo soy la que al mundo doy pena y tormento, yo soy el azote de Dios enviado, yo soy el espanto del más esforzado, al fuego perpetuo doy soplo y aliento. Al bueno pagamos su buen miramiento, si esclavo, si libre, si siervo o señor, las leyes se guardan en todo rigor; también castigamos el mal pensamiento. Descarga con tiempo tu mala conciencia, alimpia tus males, enmienda la vida, el alma remedia que tienes perdida, la tabla te valga de fiel penitencia. Con esto no temas la dura sentencia, mas antes camina con rostro sereno causado de un pecho católico y bueno. Comulga también con gran reverencia. BONIFACIO 2OO1b: 612-13

Astraea's sister Charity affirms her message, but this time with a carrot instead of a stick:

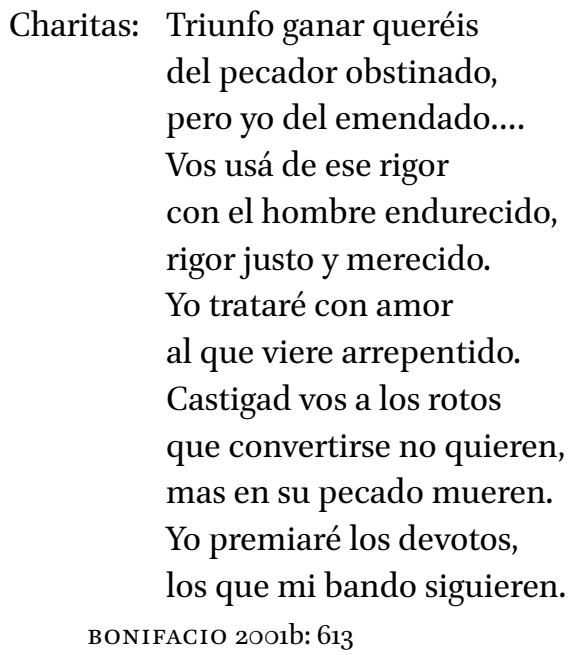


At the start of the second act, another actor offers a summary of what is about to transpire in the "Actus Secundi Brevis Expositio":

Dos hombres penitentes y cristianos

alaban al Señor de lo criado.

Habiendo los dos sido antes livianos,

escupen y abominan su pecado.

BONIFACIO 20O1b: 623

The first repentant sinner, Metaneus, then tells his story:

He sido tan pecador

y a tanto extremo llegué,

como si fuera error

lo que nos dice la fe

y afirma el predicador.

Fue mi vida tan si vida,

tan sin rienda mi correr

que, viendo el alma perdida,

gustaba de la perder,

aunque por Dios redimida.

Quisiera ser inmortal

no en la gloria ni en el cielo,

mas como bruto animal

para tener en el suelo

paraíso terrenal.

Era el mismo Lucifer

cuanto toca al pensamiento.

Lo que dejé de hacer

no era por miramiento,

sino por más no poder.

Mas, al fin, el Dios eterno,

usando de su clemencia,

me sacó de tal infierno

y me trajo a penitencia

$\mathrm{y}$ a vida de buen gobierno.

BONIFACIO 2OO1b: 624-25 
Then Cosmoparus (a.k.a. Aloysio) comes out to tell of his own repentance:

¡O triste de mí, pobre y desdichado, que en tal error viví y en tal ceguera! Regíme por reloj desconcertado; mi vida fue un dislate toda entera; con verme tan enfermo y tan llagado la cura no tomaba verdadera.... $¡ O$ qué gozo y qué contento da la limpia conciencia! Aun hasta la penitencia es un sabroso tormento.... Parece ser ya de esencia la maldad y pestilencia del honrado, y que es grandeza y estado huir de la penitencia. Mas, si a dicha se levanta de la cama de sus vicios y a Dios hace sacrificios, otro gallo ya le canta.

Si a menudo se confiesa, paga sus deudas a priesa, da ejemplo, su morada es en el templo y no con gente traviesa. BONIFACIO 2OO1b: 626-28

Metaneus responds with the injunction, "Demos gracias al Señor [...] y pidámosle humildemente que nos perdone los pecados que en semejantes acompañamientos solíamos cometer" (Bonifacio 20o1b: 628).

Later in the play, in a different vignette, Suasor tries to persuade Paradoxos (a.k.a. Gonzalo Pleiteros) - who has fallen ill - to repent before he dies:

Suasor: Mire, mi señor, que se muere; confiésese, por su vida; que todo es aire. Ponga su alma bien con [....] Mire, señor Gonzalo Pleiteros, que le toman todos los diablos, confiésese. ¿Quiere que le llamemos los Padres de S. Gil?

BONIFACIO 2001b: 636-37 
But like Nabal, Paradoxos resists this suggestion: "Paradoxos: Cuando vos os querías morir, los llamá, que os lean la Pasión y os esfuercen, que yo no he menester nada de eso" (Bonifacio 20o1b: 637). Then Melampelus comes along to try likewise to convince him to repent:

Melampelus: ¡Señor mío! ¡A, señor mío! Acuérdese de Dios. Aquí vengo a consolar a v.m. y para que tratemos de las cosas de su alma. Haga testamento y confiésese. Cumpla con Dios y con el mundo. Mire que ha vivido mal.

BONIFACIO 2001b: 637

But still Paradoxos refuses to confess, trying to convince himself that his sins aren't so bad after all:

Paradoxos: Sálganse todos, y vos el primero. Déjame aquí, que no estoy tan malo como eso. No me muero.

BONIFACIO 2001b: 638

At this instant, he does die, and Suasor laments: " $\mathrm{O}$ desastrada muerte sin confesión! ¡ $\mathrm{O}$ alma desdichada! ¡O dureza infernal! ¡O triste hado! ¡O pobre hombre!" (Bonifacio 2oorb: 638). The Chorus sums up the message of the play:

Chorus: Despierta, pecador, y ablanda el pecho, no tengas ya tan duras tus entrañas, camina por do[nde] vayas más derecho. BONIFACIO 2001b: 638

In the humorous finale, Aloysius plays confessor to his fellow rustic Leucosirus by walking him through a rudimentary examination of conscience:

Aloysius: Veamos, hermano, entre semana ¿ireñís con vuestros vecinos, enojáisos de pocas cosas, echáis maldiciones, juráis, murmuráis del cura, sois duro de condición, andáis en temas y pleitos? BONIFACIO 2001b: 647

The simpleton Leucosirus admits he used to do these bad things, but affirms proudly that he has reformed his life and does not do them any longer. In a different study I referred to this scene as "a public Jesuit stamp of approval upon this alternative, non-noble path to piety" (Kallendorf 2012: 122).

As I noted in Sins of the Fathers, sometimes "the language of sacramental confession $[\ldots]$ seems to be more about repeating the reassuring words of ritual, 
'yo confieso,' than about receiving absolution from the priest" (Kallendorf 2013: 148). The clearest example of formal sacramental confession I have found in early modern Spanish drama is in Calderón's auto El año santo de Roma. In it, the allegorical figure of Culto challenges Hombre to confess his sins and receive pardon:

Culto: Confiesa al verte

rendido a ese asombro fuerte,

que erraste.

Hombre: Ya lo confieso.

Culto: Pues yo llegaré con eso

ahora a favorecerte, que dando tú a tu Albedrío

la mano, él a tu Temor,

tu Temor a mí, el favor

del Perdón traerte confío.

CALDERÓN DE LA BARCA 1995, vv. 1658-65, 94-95

Later Amor explains this whole process to Hombre:

Amor: Cuando postrado te veías

y a Dios de temor llamabas,

no era, no, porque le amabas,

sino porque le temías;

y así, las piedades mías

no aliviaron tu pasión,

hasta que en la confesión

pudiste el acto elevar,

que Amor no puede alcanzar

donde no alcanza el Perdón.

Y aunque el haberme alcanzado,

cuando estoy de ti ofendido,

por la mano izquierda ha sido,

esa es la que yo le he dado,

porque desde tu pecado

no me alcanzaste; mas hecha

la confesión, te aprovecha

tanto, que siendo atrición

la izquierda, la confesión

la vuelve mano derecha. 
La indulgencia a que vienes, que aquí se explica, imagino, pues te da el Culto Divino el grado que tú no tienes; por él el Perdón previenes que no pudieras por ti prevenir, pudiendo aquí la Gracia que yo prometo, hacer de un acto imperfecto un perfecto acto, y así, cuando por solo temor me llamaste, no llegué; tras Culto y Perdón sí, que al Temor con su favor le da su Gracia su Amor, con que probar solicito, que el Sacramento infinito de Confesión, es bastante que el atrito se levante con méritos de contrito, y pues ahora lo estás aprovecha el tiempo ahora.

Levántase.

Teme.

Temor: Gime.

Perdón: Siente.

Albedrío: Llora.

Culto: Con eso volver podrás

donde el camino hallarás

que perdiste.

CALDERÓN DE LA BARCA 1995, vv. 1672-1717, pp. 96-98

Hombre reads aloud from Psalm 5 , the Miserere, to pray a prayer of contrition directly to God:

Hombre: [D]el libro de los días borra, Señor, iniquidades mías.

Con amplia gracia, pues tu gracia ha sido la viva fuente de inmortal pureza, lava las manchas en que me ha tenido 
el lodo vil de mi naturaleza, no porque conozco mi flaqueza y conozco que siempre conjurado va contra mí, conmigo mi pecado. Pero si confesándole acrisolo tu poder, de rebelde no me arguyas contra ti, pues, Señor, contra ti solo pequé, mi Dios, y en la presencia tuya, para que tú cuando de polo a polo a juzgar vengas, en la causa suya justifiques tu causa y me convenzas y con justicia y no poder me venzas; mas atiende, Señor, en la agonía del juicio que me aguarda prevenido que culpa de mi ser herencia es mía, pues que nací en pecado concebido.

Perdón and Culto then open the doors of the Temple to Man, signalling his absolution.

Whether or not a play includes this clear an example of sacramental ritual, the most telling indicator of whether a sinner has repented or not is a noticeable change in his or her behavior afterward. As the Jesuit playwright Guillermo Barçalo admonished the audience in his prologue to Tragedia de divite epulone, "Pido que la Tragedia no sea oyda,/por iuego, fiesta, o entretenimiento,/sino para de hoy mas mudar la vida" (cited in González Gutiérrez 1997: 228). In the early modern English tradition, Stegner quotes from a sermon contained in the Second Book of Homilies (1562), which states that "like Peter, true penitents 'must be cleane altered and chaunged, they must become newe creatures, they must be no more the same that they were before"' (Stegner 110). My assessment of this trend in Conscience on Stage was: "The explicit goal of the drama is to convince the spectators to change their lives" (Kallendorf 2007: 29).

This is the case in Calderón's comedia La exaltación de la Cruz. In the key scene, Eraclio laments that the sacred relic of the True Cross has been captured by infidels. He comes to realize his own responsibility for this disaster:

Eraclio: El sagrado Leño, que siendo arca de este diluvio, fue después de Dios humano el Carro, el Plaustro, y el Triunfo, Ultrajado; ;tal repito! 
de Bárbaros; ;tal pronuncio!

En Persia cautivo yace, sin estimación, y culto; ¡o mal hayan! ¡o mal hayan! Pero ¿̇a quién culpo, a quién culpo? ¿Si mis omisiones solas dieron materia a este insulto? Pero aunque conozco tarde el yerro que amor me puso; presto he de enmendarle, salga del lugar, donde le tuvo mal entretenido el ocio, mal aconsejado el gusto. Salga Eudocia de mi pecho, Rompe el Retrato.

y este hermoso objeto suyo, desperdiciado del aire, vuele en átomos menudos. Los aplausos de mis bodas, que el alborozo dispuso, trueque el dolor en exequias, sea el tálamo sepulcro.

No haya en mí valor, no haya en mi amor afecto alguno desde hoy, que en órden no sea a rescatar este sumo tesoro, sepa cobrarle, quien solo perderle supo.

Deudos, vasallos, y amigos, Eraclio César Augusto de Constantinopla os pide perdón del ocio en que os tuvo. CALDERÓN DE LA BARCA 1652: 67r-67v

He then lays out a plan for the True Cross's rescue:

En todo mi Imperio a un tiempo se escuchen ecos confusos de trompas, y cajas; pero bien pronunciado ninguno. Destemplado el parche gima, 
bastardo el metal robusto,
y en vez de los estandartes,
que fueron en sus dibujos,
primavera de los vientos,
el aire tremóse oscuros
tafetanes, negras sean
(en sentimiento tan justo)
banderas, plumas, y bandas;
que a tan sacrílego hurto
es bien que la Cristiandad
se vista de negros lutos.
Y yo he [de] ser el primero,
que embrazado el fuerte escudo,
que el templado arnés trenzado,
y el limpio acero desnudo,
en la campaña resista
los destemplados influjos
de las escarchas de Enero,
y de los Soles de Julio,
hasta que, o pierda la vida,
o vea si restituyo
la Cruz de Cristo al lugar
donde Elena la puso.

CALDERÓN DE LA BARCA 1652: 67v

He spends the rest of the play making valiant efforts to fulfill this vow.

Our final example of confession in the drama descends as with a microscope from macrocosm to microcosm, moving in the process to about a century later. In Luciano Francisco Comella's El dichoso arrepentimiento we find a case of true repentance declared out loud from offender to victim, but without the sacramental mediation of a priest. This may constitute a dramatic equivalent of the self-exorcism performed by Don Quijote which I have described elsewhere (Kallendorf 2002). In this play, Milord is an errant husband overcome by feelings of remorse who has returned to his abandoned wife Isabel (he had left her to chase after a wealthy woman due to his social ambition). María Angulo Egea locates this play within a broader context of social criticism aimed at lazy noblemen who found work distasteful: "Comedias como El dichoso arrepentimiento ... muestran el enfrentamiento que surge entre las antiguas concepciones y privilegios que otorgaba el honor nobiliario y las modernas ideas 
ilustradas que defienden los derechos de los virtuosos, aquellos que trabajan honradamente y hacen prosperar al país" (Angulo Egea 107). Stricken with regret, Milord laments:

No me recuerdes, esposa mis vergonzosos delitos. Ante tus ojos ¡oh Dios! me presento confundido entre mis torpes maldades.... Cómo al mirarte palpito.... Cómo me desnudo.... ¡Ay triste! ... ¡Cuánto tiempo te he tenido entre miserias! Si acaso disculparán mi delito los detestables consejos de Thovart, mi falso amigo, te diría.... Pero no, mis remordimientos mismos me acriminan.... ¡Mas qué miro! ¿Este pan grosero y tosco de alimento te ha servido? ¿Estos techos infelices te han proporcionado abrigo? ¡qué horror! ¿Para descansar de tus pesares continuos tenías el triste lecho que en el duro suelo miro? Estas penas que inocente por mi dureza has sufrido me parece que la saña excitan de los abismos. En vano esposa tu amor disculpa mis desvaríos; en vano me amas.... No tengo cosa alguna en favor mío que me pueda hacer capaz de tus piedades; yo mismo lo conozco. Eternamente en el seno del olvido 
debes tenerme; si esposa que me aborrezcas suplico sin que sobre mí derrames ningún rasgo compasivo. COMELLA [179O]: 24-25

He is horrified to find her living in such penurious conditions. Angulo Egea notes that this type of scene appears frequently in dramas by Comella:

Comella se sirvió de estas imágenes para conmover a los asistentes y para realzar la humanidad de aquellos que ayudaban a socorrer a estos menesterosos. El lado humano y especialmente emotivo de los monarcas y de los nobles ilustrados se veía reforzado con estas escenas. Por lo general, se presentaba a una familia con niños pasando hambre en una 'casa pobre,' rústica, sin más utensilios que una mesa, unas sillas y algún cacharro para cocinar, y con la omnipresencia del pan moreno como símbolo de la suma pobreza y único alimento de que se disponía. La casualidad hace que estas altas personalidades descubran semejantes cuadros y traten modestamente de aminorar los sufrimientos de estas familias [...] [E]stos retratos de miseria del pueblo no parecen pensados tanto para reflejar una realidad preocupante, como para reforzar por contraposición la imagen nueva de la monarquía y de la nobleza. Estas circunstancias lastimosas se deben a casos excepcionales, y a desgracias personales de individuos maltratados por algún tipo de injusticia concreta, que tiene que ver con la acción indigna de un malvado, que, al final de la comedia, será castigado, y la familia será también recompensada.

ANGULO EGEA 122, emphasis added

These generalizations about the rest of Comella's theatrical production make this play even more interesting; for in its ending, the villain is not punished, but instead repents of his sins in the confession scene which gives the play its title.

In response to this speech of contrition, his wife offers him - in the words of Charlotte Brontë's Jane Eyre - her "full and free forgiveness" (Brontë 1897, chapter 21):

Isabel: Calla, esposo, calla, y deja discursos tan desmedidos. ¿Cómo puede aborrecerte cómo ha de darte castigo aquella que en tu abandono 


\author{
con tantas veras te quiso? \\ Esposo vuelvo a decir, \\ que soy tuya si eres mío. \\ ¿Lo serás? \\ Milord: Sí, tierna esposa \\ pero mis negros delitos.... \\ Isabel: Todos están olvidados. \\ Milord: ¿Qué dices? \\ Isabel: Que así lo afirmo. \\ COMELLA [179o]: 25
}

This heartwarming scene concludes with an additional reconciliation between father and daughter, as Isabel and Milord's offspring sees her parents together for the first time she can remember.

As I noted in Conscience on Stage,

We must realize that it is precisely the force of repetition that enables casuistry to leave such a noticeable trace: the annual repetition, year after year, of the sacrament of penance left a trace of the discourse of conscience even upon the most casual believer. How much more so would this be the case for priest/playwrights who may even have served as confessors themselves.

KALLENDORF 2007: 107

In the aggregate, these repeated scenes of confession, repentance, resolve to change or take action, and/or reconciliation constitute a corpus of works fundamental to our ongoing study of casuistry in early modern Spanish drama. ${ }^{8}$ Scholars such as Montiel Contreras have continued my work in this vein, confirming that "los escenarios del teatro religioso popular y de colegio recrearon espacios de ficción donde los personajes, a prueba y error, exploraron resoluciones posibles. Las normas cristianas de comportamiento fueron punto de referencia para calibrar actitudes y ocasiones particulares" (Montiel Contreras 70). Even more squarely placed in the realm of casuistry is the scholarship of Joan Oleza, who affirms for example regarding a similarity of method observed between Lope de Vega and Michel de Montaigne: "la casuística que ponen en escena las comedias del poeta español se corresponde con la que le sirve para argumentar al prosista francés, pues ambas proceden por medio del examen de casos" (Oleza 54).

8 See Kallendorf 2007, Kallendorf 2013 and Kallendorf 2017. 
Ranging from off-the-cuff, humorous references; to tragic death scenes in which the services of a priestly confessor are required; to injunctions to repent, where the sinner refuses these admonitions; to full sacramental ceremony; to everything in between, these case studies serve to solidify even further the argument that the poetics of early modern Spanish drama are based on the presentation of moral dilemmas and their myriad resolutions on the stage. After viewing these scenes, spectators might feel encouraged to examine their own lives - and their own consciences - to see where they, too, might need to confess or repent. Montiel Contreras confirms that at least for the Jesuit school drama, this was definitely the case: "El teatro jesuita, como instrumento pedagógico y social, fue la forma idónea para que los casos de conciencia de los protagonistas en escena fueran también formulados en el foro interno de un amplio auditorio" (Montiel Contreras 69). As I noted in Conscience on Stage:

There are, in fact, numerous accounts suggesting that after witnessing a performance of one of these plays, the audience members did just that [i.e. examined their own consciences or resolved to change their lives]. The [Jesuit] dramatist Acevedo reported that after a performance of Euripus in Córdoba, many members of the audience swarmed to the confessional: 'no faltó quien tocado del desastrado fin de Euripo ... acudiese a la confesión' [...] Likewise, after a performance of his play Metanea (or De penitentia) in the same colegio on 1 September 1561, Acevedo wrote a letter reporting that the actors performed better as a result of having gone to confession and that the audience, in turn, was inspired to confess.

KALLENDORF 2007: 29

There is a risk in our postmodern secular era (when sacramental confession is not a weekly, monthly or even annual ritual for most playgoers) that we might lose these casuistical resonances which are no longer so culturally relevant for our times as they were for their original authors and audiences. By recapturing these allusions and recovering their original sacramental context, we hope to restore to them also their power to move our hearts. And perhaps even to stir our consciences....

\section{Works Cited}

Angulo Egea, María. Luciano Francisco Comella (1751-1812). Otra cara del teatro de la Ilustración. Alicante: Universidad de Alicante, 2006.

Antonucci, Fausta. "La materia caballeresca en el primer Lope de Vega." XXVIII Jornadas de Teatro Clásico (Almagro, 2005): 59-77. 
Bernardo de Quirós Mateo, José Antonio. Teatro y actividades afines en Ávila (Siglos XVII, XVIII y XIX). Ph.D. dissertation, Universidad Nacional de Educación a Distancia (Madrid), 1993-94.

Bonifacio, Juan. Actio quae inscribitur Nepotiana Gometius (1572). Códice de Villagarcía, Real Academia de la Historia (Madrid), no. 13, fols. 129r-138r.

Bonifacio, Juan. Tragedia Nabalis. In El Códice de Villagarcía del P.Juan Bonifacio: Teatro clásico del siglo XVI. Ed. C. González Gutiérrez. Madrid: Universidad Nacional de Educación a Distancia, 2001a: 347-406.

Bonifacio, Juan. Triumphus Circuncisionis. Códice de Villagarcía, Real Academia de la Historia (Madrid), no. 4, fols. 24v-31.

Bonifacio, Juan. Triumphus Eucharistiae. In El Códice de Villagarcía del P.Juan Bonifacio: Teatro clásico del siglo XVI. Ed. C. González Gutiérrez. Madrid: Universidad Nacional de Educación a Distancia, 2001b: 6o9-652.

Brontë, Charlotte. Jane Eyre: An Autobiography. London: Service \& Paton, 1897. Digital edition transcribed by David Price for Project Gutenberg. https://www.gutenberg .org/files/126o/126o-h/126o-h.htm.

Calderón de la Barca, Pedro. El año santo de Roma (loa). Digital version based on the critical edition of Pedro Calderón de la Barca, Lo que va del hombre a Dios. Eds. Ignacio Arellano and Ángel L. Cilveti. Pamplona/Kassel: Universidad de Navarra/Reichenberger, 1995. http://www.cervantesvirtual.com/obra/el-ano-santo -de-roma--o/.

Calderón de la Barca, Pedro. La exaltación de la Cruz. In Primera parte de Comedias escogidas de los mejores de España. Madrid: Domingo García Morras, 1652: 62r-85v.

Chouza-Calo, María del Pilar. "Sangre y llanto: escenificación de la violencia en El marqués de Mantua de Lope de Vega." eHumanista 44 (2020): 1-15.

Comella, Luciano Francisco. El dichoso arrepentimiento (179o). N.p.: n.p., n.d. Depósito Académico Digital, Universidad de Navarra. https://dadun.unav.edu/ handle/10171/28353.

Del Río Parra, Elena. Cartografías de la conciencia española en la Edad de Oro. Mexico City: Fondo de Cultura Económica, 2008.

Derrida, Jacques. "Structure, Sign and Play in the Discourse of the Human Sciences." Writing and Difference. Trans. Alan Bass. Chicago: University of Chicago Press, 1978: 278-94.

Douay-Rheims Bible. http://www.biblehub.com/drb.

Espín Templado, María Pilar. “Disposición temática en 'El marqués de Mantua,' tragicomedia de Lope de Vega." Epos: Revista de Filología 5 (1989): 165-82.

González Gutiérrez, Cayo. "El P. Juan Bonifacio, dramaturgo." Epos: Revista de Filología 10 (1999): 467-92.

González Gutiérrez, Cayo. El teatro escolar de los jesuitas (1555-1640) (Su influencia en el Teatro del Siglo de Oro). Oviedo: Universidad de Oviedo, 1997. 
González Gutiérrez, Cayo. "El Teatro en los Colegios de Jesuitas y su influencia en la Comedia nacional del siglo XVII." Entemu: Revista de la Universidad Nacional de Educación a Distancia 3 (1991): 87-110.

Kallendorf, Hilaire. Ambiguous Antidotes: Virtue as Vaccine for Vice in Early Modern Spain. Toronto: University of Toronto Press, 2017.

Kallendorf, Hilaire. Conscience on Stage: The Comedia as Casuistry in Early Modern Spain. Toronto: University of Toronto Press, 2007.

Kallendorf, Hilaire. "The Diabolical Adventures of Don Quixote, or Self-Exorcism and the Rise of the Novel." Renaissance Quarterly 54.1 (2002): 193-223.

Kallendorf, Hilaire. "Dressing a Salad, Clothing with Virtue; or, Is One Language More Righteous than Another?" St Francis Xavier and the Jesuit Missionary Enterprise: Assimilations between Cultures/San Francisco Javier y la empresa misionera jesuita. Asimilaciones entre culturas. Eds. Ignacio Arellano and Carlos Mata Induráin. Pamplona: Servicio de Publicaciones de la Universidad de Navarra, 2012: 113-23. [BIADIg, Biblioteca Áurea Digital-Publicaciones Digitales del GRIso] http://www .unav.es/publicacion/sfj-navarro-universal/publicacion.

Kallendorf, Hilaire. Sins of the Fathers: Moral Economies in Early Modern Spain. Toronto: University of Toronto Press, 2013.

Kallendorf, Hilaire. "Splitting Hairs or Finding Threads: The Labyrinth as Metaphor for Moral Dilemma in the Comedia." Docta Y SABIA ATENEA. Studia in honorem Prof. Lía Schwartz. Eds. Sagrario López Poza et al. A Coruña: Universidade da Coruña (2019): $339-58$.

Kamen, Henry. "Religion." A Companion to the Spanish Renaissance. Ed. Hilaire Kallendorf. Leiden: Brill, 2019: 186-204.

Lope de Vega, Félix. El marqués de Mantua. Ed. Felipe B. Pedraza Jiménez. Comedias, Parte XII. Tomo II. Ed. Prolope. Coord. José Enrique Laplana Gil. Madrid: Gredos, 2013: 3-153.

Montiel Contreras, Carlos-Urani. “Competencia entre compañías: la escenificación de Nabal Carmelo por comediógrafos y jesuitas.” TeatrEsco 5 (2012-13): 57-72.

Oleza, Joan. "De Montaigne a Lope: distintos resultados de una misma decisión." Revista de Literatura 71.141 (2009): 39-56.

Pedraza Jiménez, Felipe B. "Personas reales y justicia poética: Lope, Guillén de Castro, Rojas Zorrilla." Lectura y Signo 2 (2007): 129-56.

Pedraza Jiménez, Felipe B. "Prólogo" a El marqués de Mantua. In Lope de Vega, Comedias, Parte XII. Tomo II. Ed. Prolope. Coord. José Enrique Laplana Gil. Madrid: Gredos, 2013: 3-23.

Pedraza Jiménez, Felipe B. Sexo, poder y justicia en la comedia española: cuatro calas. Vigo: Editorial Academia del Hispanismo, 2007b.

Pérez García, Norberto. "Lope de Vega, Jerónimo Cáncer y las dramatizaciones áureas de los romances del marqués de Mantua." Cuadernos para Investigación de la Literatura Hispánica 26 (2001): 189-2006. 
Rosselló Castillo, Luisa. "Algunas ideas sobre la monarquía en dos comedias de Lope de Vega con el príncipe enamorado." Pensamiento y literatura en los inicios de la modernidad. Ed. Jaume Garau. New York: Instituto de Estudios Auriseculares, 2017: 147-89.

Ruiz del Vizo, Hortensia. El Marqués de Mantua (Simbolismo y Evangelio en Lope de Vega). Miami: Universal, 1971.

Sánchez Jiménez, Antonio. Review of Hilaire Kallendorf, Sins of the Fathers: Moral Economies in Early Modern Spain. RILCE 32.2 (2016): 577-83.

Stegner, Paul D. “Try what repentance can': Hamlet, Confession, and the Extraction of Interiority." Confession and Memory in Early Modern English Literature. London: Palgrave Macmillan, 2016: 105-29.

Ximénez, Francisco. Diálogo hecho en Sevilla ... a la venida del padre visitador a las Escuelas.... a la venida del padre visitador a las Escuelas. La Tragedia de San Hermenegildo y otras obras del teatro español de colegio. Ed. Julio Alonso Asenjo. Valencia: Universidad Nacional de Educación a Distancia, Universidad de Sevilla, and Universitat de València, 1995: 1:362-422. 